\title{
Konsep Penataan Ruang Terbuka Hijau Publik Di Kota Kecamatan Mengwi, Kabupaten Badung, Provinsi Bali
}

\author{
I MADE AGUS DHARMADIATMIKA* \\ Program Studi Arsitektur Pertamanan, Fakultas Pertanian, Universitas Udayana \\ JI. PB. Sudirman-Denpasar, 80362 \\ *E-mail: dharmadiatmika@unud.ac.id
}

\begin{abstract}
The Concept of Public Green Open Space Structuring in the City of Mengwi Sub-District, Badung Regency, Bali Province
\end{abstract}

The purpose of this paper is to determine a plan of action structuring public green open space in the City of Mengwi, Knowing efforts to increase the quantity of green space in the City of Mengwi, and know the concept of development and structuring of public green open space in the City of Mengwi. This paper uses a qualitative approach with a phenomenological approach. The action plan structuring public green open space in the City of Mengwi action oriented with using this type of local parks, the action attribute applicative green city, square garden action, and action structuring neighborhood parks. Improving the quality of green space through enhancing functionality of existing green space, an increase in the proportion of green space utilization through neighborhood scale park like garden telajakan so that the amount of public open space can grow. The concept of the development of public green space in the City of Mengwi is based on the concept of implementing arrangement with green attributes, use local vegetation and observe the movement of the user system. Maximizing green space telajakan began by supplying bags garden is in the area of commercial and office.

Keywords: green open spaces, green city, concept

\section{Pendahuluan}

Ketersediaan ruang terbuka hijau (RTH) di wilayah perkotaan merupakan bagian pembentuk struktur ruang kota dan alat yang secara bersinergi mendukung pembangunan perkotaan secara berkelanjutan dan juga memiliki fungsi menunjang faktor ekologis perkotaan. Guna menunjang ketersediaan RTH, peran pemerintah dan kepedulian masyarakat sangat penting. Kepedulian masyarakat dan mewujudkan keberlangsungan tata kehidupan kota, antara lain dapat dilakukan dalam bentuk perwujudan kota yang menjamin keberadaan ruang terbuka hijau. Amanat ini tidak terlepas dari Undang-Undang No. 26 Tahun 2007 yang secara tegas menyatakan bahwa 30\% dari wilayah kota berwujud Ruang Terbuka Hijau (RTH), 20\% RTH publik dan 10\% RTH privat. 30\% luasan ruang terbuka hijau kota merupakan ukuran minimal untuk menjamin keberlangsungan 
keseimbangan ekosistem kota yang didalamnya meliputi keseimbangan sistem hidrologi, keseimbangan mikroklimat, dan sistem ekologis lain yang dapat meningkatkan ketersediaan udara bersih yang diperlukan masyarakat, ruang terbuka bagi aktivitas publik serta sekaligus dapat meningkatkan nilai estetika kota (Hakim,2004). Isu-isu mengenai degradasi lingkungan dan dampak urbanisasi merupakan masalah kota-kota didalam negara berkembang. Pertumbuhan kota hanya menitik beratkan peningkatan sektor ekonomi, sehingga banyak lahan di perkotaan dikonversikan menjadi lahan terbangun. Kondisi ini juga diperparah dengan cendrungnya para stakeholder memprioritaskan pembangunan ekonomi sehingga memiliki profit pendapatan ekonomi yang tinggi.

Terkait dengan hal tersebut, di Kabupaten Badung sendiri, berbasis utamanya adalah sektor pariwisata, juga mengalami permasalahan mengenai keberadaan ruang terbuka hijau, khususnya pada kawasan perkotaan. Kabupaten Badung memiliki 5 Kota Kecamtan antara lain: Kota Kecamtan Abiansemal, Kota Kecamatan Mengwi, Kota Kecamatan Kuta Utara, Kota Kecamatan Kuta dan Kota Kecamatan Kuta Selatan. Namun, pada kenyataannya tidak didukung dengan adanya RTH publik yang mampu berfungsi secara ekologis, estetika maupun sosial budaya dan ekonomi. Seiring dengan adanya Pusat Pemerintahan Mangupraja Mandala dengan adanya Kota Mangupura yang terletak di Kecamatan Mengwi, sudah sepatutnya perencanaan ruang terbuka hijau di rencanakan sejak dini. Upaya tersebut dimulainya dengan menyediaan ruang publik di Kota Kecamatan Mengwi melalui pengadaan konsep RTH yang tepat. Kota Kecamatan Mengwi dipilih dikarenakan memiliki RTH yang paling luas dibandingkan Kota Kecamatan lainnya. Upaya merencanakan RTH merupakan konsistensi Pemda Kabupaten Badung guna menciptakan RTH publik sesuai dengan amanat UU yang telah diberikan. Dengan mulainya menyediakan RTH publik di Kota Kecamatan Mengwi, nantinya mampu ditularkan ke Kota Kecamatan lainnya di Kabupaten Badung. Dalam perencanaannya meningkatkan kualitas RTH publik seyogyanya mampu menciptakan nilai keamanan, kenyamanan, pencapaian, vitalitas, dan citra (image) (Darmawan, 2009:88-89). Berdasarkan pemaparan latarbelakang, penelitian bertujuan mengetahui mengetahui konsep penataan ruang terbuka hijau publik di perkotaan kabupaten badung khususnya di Kota Kecamatan Mengwi, mengetahui upaya peningkatan kuantitas ruang terbuka hijau di Kota Kecamatan Mengwi, dan mengetahui elemen-elemen penunjang ruang terbuka hijau publik di Kota Kecamatan Mengwi.

\section{Metode Penelitian}

Penelitian dilakukan di Kota Kecamatan Mengwi, Kabupaten Badung. Pendekatan penelitian yang digunakan dalam studi ini adalah pendekatan kualitatif yang dipilih untuk menemukan pola hubungan yang bersifat interaktif dalam merencanakan konsep RTH publik serta memahami fenomena dilapangan. Data yang dikumpulkan dalam penelitian ini adalah data primer dan data sekunder. Data primer meliputi obeservasi, materi dan wawancara terhadap aparatur pemerintah yang memiliki tugas pokok dan fungsi terkait dalam merencanakan dan mengadaakan RTH publik. Responden yang dipilih hanya terbatas pada pemerintah/SKPD Kabupaten Badung (Bappeda, dan DKP) dan masyarakat setempat dikarenakan penelitian ini hanya meneliti rencana konsep pengadaan RTH di Kota Kecamatan Mengwi. Jumlah informan 20 orang yang bekerja dilingkungan Bappeda dan DKP Badung yang membidangi perencanaan RTH. Jumlah masyarakat sebagai informan sebanyak 60 orang, masing-masing lokasi 10 orang informan yang sedang melakukan aktivitas di RTH tersebut. 
Pertanyaan wawancara tersusun sama terhadap narasumber berdasarkan kebutuhan penelitian. Sedangkan data sekunder berupa data survey, peta, tabel dan uraian data terkait. Teknik analisa yang digunakan dalam mengidentifikasi proporsi ruang terbuka hijau Kota Kecamatan Mengwi digunakan teknik analisa deskriptif dengan aplikasi matematis secara sederhana untuk mendapatkan besaran ruang terbuka hijau terhadap luasan Kota Kecamatan Mengwi. Selanjutnya teknik analisa yang dipergunakan untuk mengetahui konsep RTH Kota Kecamatan Mengwi adalah dengan teknik analisa deskriptif melalui mengelompokkan hasil data wawancara kebutuhan masyarakat akan RTH publik kemudian dilanjutkan dengan mencocokkan data hasil wawancara tehadap intansi pemerintah. Hasil analisa tersebut kemudian dilanjutkan dengan kroscek kondisi RTH dilapangan dengan memperhatikan referensi RTH.

\section{Hasil dan Pembahasan}

Ruang terbuka hijau dikenal dengan istilah RTH, merupakan istilah yang telah lama diperkenalkan. Pedoman tentang penataan ruang terbuka hijau di wilayah perkotaan (Inmendagri Nomor 14 Tahun 1988), menegaskan bahwa untuk meningkatkan kualitas hidup di wilayah perkotaan yang mencakup bumi, air, ruang angkasa dan kekayaan yang terkandung didalmnya, maka diperlukannya upaya untuk mempertahankan dan mengembangkan kawasan-kawasan hijau. Menurut Darmawan (2009:48) menyatakan bahwa ruang publik dibagi menjadi beberapa tipe dan karakter diataranya: taman umum (publik parks), lapangan dan plaza (squares and plazas), peringatan (memorial), pasar (markets), jalan (streets), tempat bermain (play ground), ruang komunitas (community open space), jalan hijau dan jalan taman (greenway and parkways), atrium/pasar di dalan ruang (atrium/ indoor market place), ruang lingkungan rumah (found/neighborhood spaces), dan Water front. RTH dalam pemanfatannya lebih bersifat pengisian hijau tanaman atau tumbuh-tumbuhan secara alamiah maupun budidaya tanaman seperti lahan pertanian, pertamanan, perkebunan dan sebagainya.

Menurut Hakim dan Hardi (2003) ruang terbuka merupakan ruang umum yang merupakan bagian dari lingkungan yang memiliki pola. Selanjutnya Itja (2009) mengemukakan bahwa ruang terbuka (open spaces) merupakan ruang yang direncanakan karena kebutuhan akan tempat-tempat pertemuan dan aktivitas bersama di udara terbuka. Ruang umum adalah tempat atau ruang yang terbentuk karena adanya kebutuhan akan perlunya tempat untuk bertemu atau berkomunikasi satu sama lainnya. Dengan adanya kegiatan pertemuan bersama-sama antara manusia, maka kemungkinan akan tumbul bermacam - macam kegiatan pada ruang umum tersebut.

Departemen Arsitektur Lansekap IPB (2005) menyebutkan bahwa RTH kota adalah bagian dari ruang-ruang tebuka (open spaces) suatu wilayah perkotaan yang diisi oleh tanaman, dan vegetasi (endemik, introduksi) guna mendukung manfaat langsung dan atau tidak langsung yang dihasilkan oleh RTH dalam kota tersebut yaitu keamanan, kenyamanan, kesejahteraan, dan keindahan wilayah perkotaan tersebut.

Menurut Hakim dan Hardi (2003) penataan ruang terbuka hijau secara tepat akan mampu berperan meningkatkan kualitas atmosfer kota, menyegarkan kota, menurunkan suhu kota, menurunkan kadar polusi udara, dan merendam kebisingan. Sedangkan Hakim dan Hardi (2003) menyatakan bahwa pada umumnya ruang terbuka hijau didominasi oleh tanaman, dimana unsur ini banya berpengaruh terhadap kualitas udara kota. Tanaman dapat menciptakan iklim mikro, yaitu adanya penurunan suhu sekitar, kelembaban yang cukup dan kadar oksigen yang bertambah. 
Secara geografis Kabupaten Badung terletak antara 08 $14^{\prime} 20^{\prime \prime}$ - 08 $50^{\prime} 48^{\prime \prime}$ LS (Lintang Selatan) dan $115^{\circ} 05^{\prime} 00^{\prime \prime}$ - 115 26' 16" BT (Bujur Timur), dengan luas wilayah $418,52 \mathrm{Km} 2$ atau sekitar 7,43 \% dari daratan Pulau Bali. Kawasan perkotaan yang dimaksud dalam penelitian ini meliputi 5 kawasan perkotaan di Kabupaten Badung yaitu kawasan Kota Kecamatan Kuta Selatan, kawasan Kota Kecamatan Kuta, kawasan Kota Kecamatan Kuta Utara, kawasan Kota Kecamatan Mengwi, dan kawasan Kota Kecamatan Abian Semal.

Kawasan perkotaan di Kabupaten badung secara keseluruhan memiliki luas sebesar 37.955,30 Ha yang terbagi atas lima wilayah perkotaan dengan luasan sebagai berikut : Kawasan Kota Kecamatan Kuta Selatan dengan luasan wilayah 10.113,00 H, Kawasan Kota Kecamatan Kuta dengan luasan wilayah 1.917,65 Ha, Kawasan Kota Kecamatan Kuta Utara dengan luasan wilayah 2.213,00 Ha, Kawasan Kota Kecamatan Mengwi dengan luasan 3.587,00 $\mathrm{Ha}$, Kawasan Kota Kecamatan Abiansemal dengan luasan 1.093,00 Ha (DKP Badung, 2013).

Dari data tersebut disebutkan bahwa kawasan yang menjadi obyek penelitian merupakan kawasan yang menjadi lbu Kota Kabupaten Badung yaitu pusat Kota Mangupura yang berada di Kota Kecamatan Mengwitani yang memiliki luas 3.587,00 Ha sehingga kebutuhan ruang terbuka hijau hijau (RTH) kawasan pusat kota kabupaten badung jika disesuaikan dengan pendapat Budiharjo (2003) yang menyatakan bahwa 30\% hingga 50\% dari keseluruhan luasan kota diperuntukkan bagi ruang terbuka hijau kota adalah sebasar kurang lebih 1.076,1 Ha dari luasan kawasan kota mengwi secara keseluruhan. Kota Kecamatan Mengwi terbagi atas 20 Desa/kelurahan yaitu, Cemagi, Munggu, Pererenan, Tumbakbayuh, Buduk, Abianbase, Sempidi, Sading, Lukluk, Kapal, Kekeran, Mengwitani, Mengwi, Gulingan, Penarungan, Baha, Werdi Bhuana, Sobangan, Sembung, dan Kuum. Kawasan ini cendrung merupakan kawasan pengembangan pertumbuhan ekonomi akibat adanya pusat Kota Mangupura, akibatnya banyak kawasan yang strategis dan cendrung berkembang menjadi pusat ekonomi sehingga banyak kawasan mengalami perubahan fungsi yaitu menjadi kawasan campuran/Mix-use area (perumahan, perdagangan dan perkantoran dan mengakibatkan berkurangnya luasan RTH pada kawasan Kota MengwiJika dijumlahkan secara keseluruhan luas RTH publik pada kawasan kota mengwi tahun 2013 dapat dilihat pada Tabel 1.

Tabel 1. Rekapitulasi luasan RTH di kawasan perkotaan Kabupaten Badung Tahun 2013

\begin{tabular}{|c|c|c|c|c|c|c|c|}
\hline \multirow[t]{2}{*}{ No } & \multirow[t]{2}{*}{ Jenis RTH Publik } & \multicolumn{5}{|c|}{ Kawasan Perkotaan } & \multirow[t]{2}{*}{ Total } \\
\hline & & $\begin{array}{l}\text { Kuta } \\
\text { Selatan }\end{array}$ & Kuta & Kuta Utara & Mengwi & Abiansemal & \\
\hline 1 & Lapangan & 4.01 & 7.92 & 1.71 & 10.19 & 3.09 & 26.92 \\
\hline 2 & Hutan Kota & 392.92 & 251.33 & - & - & - & 644.25 \\
\hline 3 & Jalur Hijau & - & - & - & 414.75 & - & 414.75 \\
\hline 4 & Jalur Hijau Jalan & 2.69 & 3.50 & 0.08 & 0.66 & 0.02 & 6.95 \\
\hline 5 & Radius Mata Air & - & - & - & 94.97 & 25.12 & 120.09 \\
\hline 6 & Kuburan & 7.26 & 1.22 & 0.01 & - & 0.20 & 8.69 \\
\hline 7 & Setra & 14.12 & 5.88 & 2.38 & 4.92 & 5.31 & 32.61 \\
\hline 8 & Jumlah (Ha) & 421.00 & 269.85 & 4.18 & 525.49 & 33.74 & $1,254.26$ \\
\hline 9 & $\begin{array}{l}\text { Luasan Kawasan } \\
\text { Perkotaan }(\mathrm{Ha})\end{array}$ & $10,113.00$ & $1,971.65$ & $2,213.00$ & $3,587.00$ & $1,093.00$ & $18,977.65$ \\
\hline 10 & $\begin{array}{l}\text { Prosentase } \\
\text { Terbuka (\%) }\end{array}$ & 4.16 & 13.69 & 0.19 & 14.65 & 3.09 & 6.61 \\
\hline
\end{tabular}

Sumber : DKP Badung 2013 
Dari tabel tersebut dapat dilihat luasan RTH kawasan perkotaan mengwi sebesar 525,49 $\mathrm{Ha}$ dari luasan perkotaan sebesar $3.587,00 \mathrm{Ha}$. Jika dihitung dengan perbandingan luasan keseluruhan kawasan pusat kota dengan luasan keseluruhan ruang tebuka hijau maka akan didapatkan proporsi esksisting dari ruang tebuka hijau sebesar $14.65 \%$. dari data tersebut dapat dilihat bahwa kebutuhan ruang tebuka hijau kawasan perkotaan masih kurang yang diatur oleh undang-undang atau sebesar 30\% dari keseluruhan luas wilayah. Sehingga untuk mencapai proporsi RTH publik yang ideal dibutuhkan penggunaan lahan kurang lebih 20\% dari keseluruhan luasan Kota Kecamatan Mengwi yaitu sebesar kurang lebih $717.4 \mathrm{Ha}$.

Kondisi eksisting ruang tebuka hijau publik Kota Kecamatan Mengwi memiliki karakteristik ruang terbuka hijau yaitu gambar 1 :

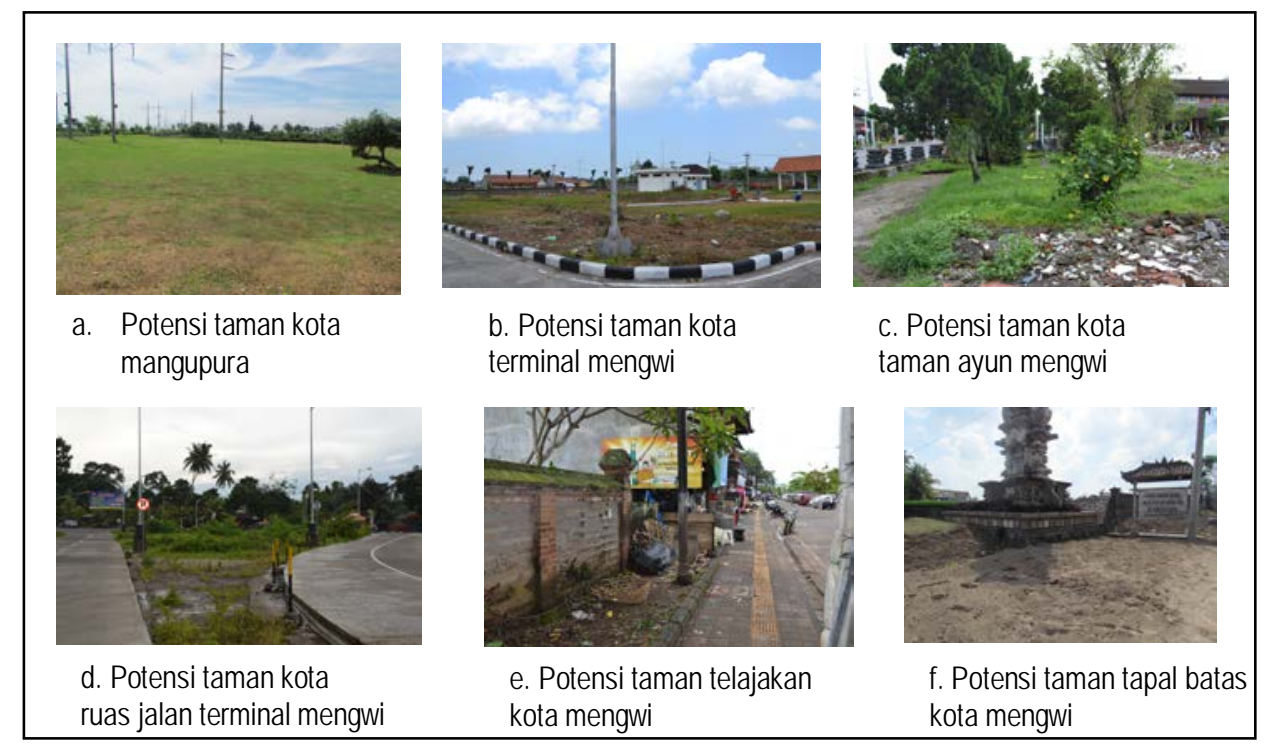

Gambar 1. Identifikasi Ruang Terbuka Hijau Publik Pada Kota Kecamatan Mengwi

1. Ruang terbuka hijau publik yaitu berupa lapangan dan taman kota sebesar $10.85 \mathrm{Ha}$.

2. Ruang tebuka hijau publik yaitu berupa jalur hijau berupa lahan pertanian dan perkebunan sebesar $414.75 \mathrm{Ha}$.

3. Ruang tebuka hijau publik yaitu berupa jalur hijau jalan berupa taman telajakan, dan tapal batas kabupaten sebesar sebesar $0.66 \mathrm{Ha}$.

4. Ruang tebuka hijau publik yaitu berupa radius sumber mata air sebesar $94.97 \mathrm{Ha}$.

5. Ruang tebuka hijau publik yaitu berupa setra sebesar $4.92 \mathrm{Ha}$.

Dari penelitian ini didapatkan hasil eksplorasi terdapat tiga tahap eksplorasi yaitu fungsi RTH di Kota Kecamatan Mengwi : Eksplorasi fungsi ekologis : masyarakat sebagai pengguna merasakan manfaat akan keberadaan ruang terbuka hijau sebagai pencipta iklim mikro. Jenis dan keragaman vegetasi, penentuan lokasi ruang terbuka hijau dan penggunaan material yang alami sangat berpengaruh sebagai faktor penentu terciptanya iklim mikro pada ruang terbuka hijau. Ruang terbuka hijau di kawasan mengwi dirasakan belum mampu menyerap polusi dan debu akibat penggunaan jumlah vegetasi yang menyerap polusi belum maksimal. Belum maksimalnya penggunaan vegetasi yang mendukung terciptanya fungsi sebgai penunjang kualitas ekologis pada kawasan pusat kota. 
Dari hasil wawancara fungsi estetika didapat bahwa ruang terbuka hijau publik Kota Kecamatan Mangwi masih kurang tertata dengan baik, selain itu penggunaan variasi vegetasi dengan berbagai macam ragam warna dan bentuk tajuk dan daun perlu ditambahkan sehingga menambah kesan estetika. Fungsi sosial budaya dan ekonomi, diperoleh beberapa hasil yaitu: masyarakat kususnya sebgai pengguna taman kota membutuhkan ruang untuk dipergunakan sebagai tempat beraktivitas secara sosial maupun budaya. Pemanfaatan ruang terbuka yang belum maksimal digunakan sebagai taman kota. Perlunya ruang yang intrgrasi yang memfasilitasi adanya kegiatan ekonomi didalamnya sehingga RTH tersebut dapat bermanfaat bagi masyarakat sekitar.

Kebutuhan masyarakat akan keberadaan ruang terbuka hijau pada kawasan perkotaan mengwi dapat disimpulkan jikat terkait dengan fungsi ekologisnya maka keberadaan RTH publik akan dapat meningkatkan kualitas hidup masyarakat melalui menciptakan iklim mikro yang kondusif melalui pengurangan polusi udara, menambah oksigen dan mampu mengurangi debu aktifitas perkotaan melalui pemilihan vegetasi yang tepat. Penggunaan vegetasi dengan menggunakan lebih banyak jenis tanaman perindang yang aman, dengan dahan/ranting yang tidak mudah patah dan perakaran yang tidak merusak bangunan lain. Penambahan penggunaan tanaman semak dan perdu yang memiliki estetika dan menggunakan tanaman lokal setempat maupun tanaman tradisional bali. Tanaman harus mampu menarik perhatian satwa seperti burung sehingga menciptakan iklim ekologis yang dapat bermanfaat bagi mahluk hidup didalamnya. Jika dikaitkan dengan fungsi estetika dari ruang terbuka hijau didapatkan hasil penggunaan vegetasi yang memiliki tekstur daun dan bentuk tajuk yang bervariasi serta pemilihan jenis vegetasi dengan warna daun dan bunga yang menarik untuk menghilangkan kesan monoton yang ada pada keseluruhan RTH pada kawasan perkotaan mengwi.

\section{Konsep Penataan Ruang Terbuka Hijau Publik Taman Kota/Taman Jepun Dunia}

Berdasarkan hasil wawancara dan observasi konsep penataan ruang terbuka hijau publik di Kota Kecamatan Mengwi berawal dari mulai adanya penataan di pusat Pemerintahan Mangupraja Mandala dengan adanya taman jepun yang memiliki luas 5000 $\mathrm{m}^{2}$ dimana keberadaannya mampu memfasilitasi kebutuhan masyarakat dengan memasukkan unsur ekologis, fungsi estetika, dan fungsi sosial budaya ekonomi dari ruang terbuka hijau kota melalui pemenuhan proporsi dan distribusi ideal ruang terbuka hijau kota. Dengan adanya konseppembangunan taman jepun maka mampu meningkatkan proporsi RTH kota mengwi sekitar $0.14 \%$. adanya perhatian pemerintah setidaknya mampu memberikan ruang-ruang terbuka yang dapat dimanfaatkan oleh masyarakat Kota Kecamatan Mengwi. Terciptanya taman-taman lingkungan dalam lingkungan perumahan yang mampu melayani masyarakat memaksimalkan penghijauan untuk meningkatkan nilai ekologis dan estetika perkotaan melalui penataan lansekap.

Melihat peruntukannya sebagai taman kota yang mengusung konsep 6 (enam) green, dan elemen di dalamnya dapat di jabarkan sebagai berikut : Green Transportation: merupakan jalur pejalan kaki meliputi jogging trak dan jalur terpai, plasa, dan parkir sepeda. Green Waste: taman harus dilengkangkapi dengan tempat sampah dengan terdapat 3 pilahan sampah yaitu, sampah organik, dan sampah metal. Selain itu terdapat tempat pencacah sampah agar nantinya smpah yang dihasilkan RTH tersebut dapat di manfaatkan kembali untuk RTH tersebut. Green Water: dilengkapi dengan sumur resapan, 
dan bak tampungan air hujan sehingga setiap taman tidak menggunakan sumur bor dalam pemeliharaan taman. Green Energy: menggunakan sumber energy yang dapat diperbaharui seperti penggunaan surya panel/surya sell sebagai sumber energi penerangan RTH, pembangin energi untuk pompa dan aktivitas lainnya. Green Open Space: di taman jepun pohon yang dipergunakan adalah pohon jenis jepun (Plumeria rubra). Pohon ini merupakan maskot Kabupaten Badung dan tanaman lokal di daerah Bali. Selain itu penggunaan tanaman perindang diantaranya keraipayung (Filicium decipiens), Tabebuia perindang (Penta phylla), dan cempaka (Michelia campaca). Ketiga jenis vegetasi tersebut merupakan jenis vegetasi perindang dengan nilai visual dari tajuk dan bunga. Jenis semak dan perdu yang digunakan adalah jenis tanaman puring (Codiaeum variegatum), Tanaman Pedang-pedangan (Sansiviera trifasciata) dimana tanaman ini memiliki keunggulan bentuk daun dan warna daun yang menarik serta mampu menyerap polutan. Jenis penutup tanah yang dipergunakan adalah jenis rumput manila (Zoysia matrella). Green Building: fasilitas-fasilitas didalammnya berupa toilet, papan nama taman, pos keamanan, dan lain sebagainya menggunakan bahan yang ramah lingkungan. Dapat pula di padu padankan dengan menggunakan tanaman sebgai pelunak material bahan bangunan.

Secara keseluruhan rencana RTH taman kota/taman jepun dunia menekankan pada penggunaan jepun/ tanaman lokal sebagai poin utama perencanaan taman ini. Tanaman jepun yang di gunakan adalah tanaman jepun dari berbagai jenis di seluruh dunia. Diharapkan taman ini dapat menjadi edukasi dan pemahaman, dan kecintaan masyarakat terhadap tanaman lokal daerah. Ada pun rencana taman jepun dunia dapat dilihat pada gambar 2 .

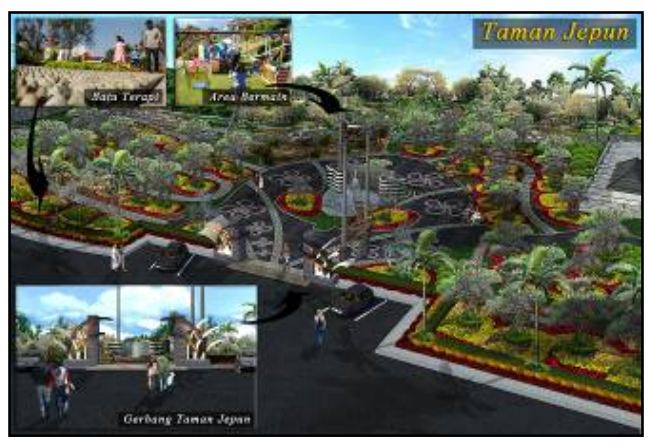

Gambar 2. Konsep Penataan Taman Kota Berorientasi Tanaman Lokal (DKP, 2013)

3. Konsep Penataan Ruang Terbuka Hijau Publik Taman Kota Pengelolaan Sampah Terpadu

Konsep penataan taman dengan konsep berkelanjutan berlokasi di area kawasan terminal mengwitani dengan luasan $7100 \mathrm{~m}^{2}$ yang diharapkan mampu menambah RTH publik di kota mengwi. Green Transportation: tidak jauh berbeda dengan taman jepun dunia taman ini harus dilengkapi dengan jalur trak pejalan kaki, dan jalur sepeda. Yang unik adalah konsep green transportation untuk sepeda mampu memberikan akses dari taman jepun ke taman kota lainnya. Dimaksudkan masyarakat mulai menggunakan saran transportasi yang ramah lingkungan. Green Waste: penggunaan bahan-bahan yang dapat digunakan kembali seperti tempat duduk dengan bahan kayu bekas atau drum bekas yang di tambahkan kegunaannya. Green Water: dilengkapi dengan biopori, sumur resapan, dan bak tampungan air hujan. Green Energy: semua RTH publik direncanakan menggunakan 
sumber energi bertenaga surya/surya sell. Penggunaan surya sel sebagai sumber penerangan mampu mengurangi beban anggaran pada biaya penggunaan energy listrik. Green Open Space: tanaman yang digunakan di taman ini lebih berpariasi, dengan tajuk yang lebar, dahan dan ranting yang kuat yang mendukung menciptakan iklim mikro bagi pengguna. Green Building: sarana tidak jauh berbeda dengan konsep RTH publik di taman jepun dunia, namun pada taman ini ruang pengelolaan sampahnya lebih diutamakan dengan menyediakan TPST terpadu dalam taman ini. Hal ini direncanakan dikarenakan letak taman ini di terminal mengwi sehingga diharapkan sampah-sampah hasil dari terminal dapat diolah dan dimanfaatkan untuk taman ini. Konsep rencana RTH publik ini diharpkan mampu memberikan kontribusi kepada masyarakat mengingat masih minimnya ketersediaan RTH publik yang dapat diakses oleh masyarakat gambar 3.

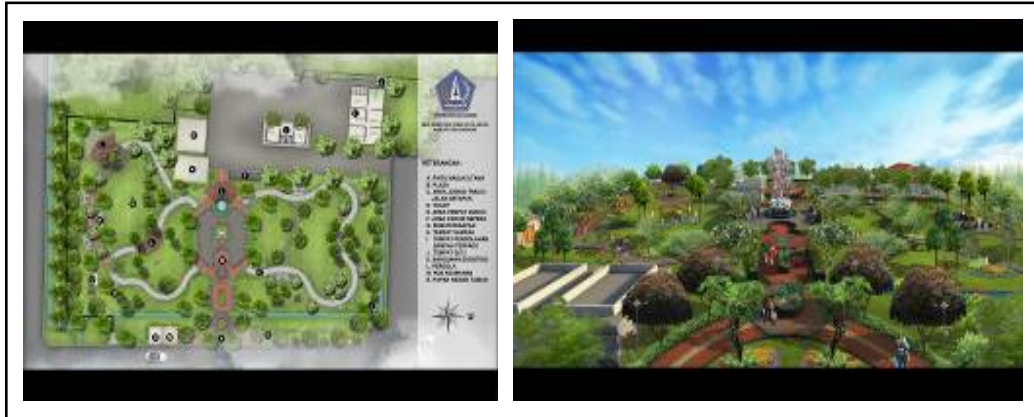

Gambar 3. Konsep Penataan Taman Dengan Konsep Keberlanjutan (DKP, 2013)

\section{Konsep Penataan Taman Jalur Hijau Jalan Dan Pulau Jalan}

Taman jalur hijau jalan konsep berpusat di sepanjang jalan menuju terminal mengwitani dengan konsep 6 green. Green Transportation berupa jalur pejalan kaki, Green Waste berupa tempat duduk, dan tempat sampah, Green Energy berupa lampu dengan tenaga surya panel, Green Open Space berupa tanaman jenis palem sebagai pengarah pandangan dan semak yang dominan berbunga, dan Green Building berupa bangunan toilet dan papan nama taman. Secara mendasar yang membedakan adalah posisi dan fungsi keberadaan taman tersebut.

Fungsi dari taman ini adalah sebagai pengatur jalur transportasi yang ditata secara terpadu. Pada jalur hijau pulau jalan meliputi taman tapal batas, taman median jalan, taman intersection/ taman pulau jalan didominasi pleh penggunaan vegetasi yang mampu menyerap polusi dan debu dengan perpaduan warna dan tekstur daun sehingga menciptakan kesan estetis. Taman pulau jalan di kota mengwi memiliki luas kurang leih $3700.70 \mathrm{~m}^{2}$. Adanya landmark berupa patung dan elemen air sebagai elemen pelembut didalamnya sehinga mampu memeberikan kesan dan nilai histori kawasan. Adanya vegetasi sebagai pengarah jalan dan pembatas jalan gambar 4 .

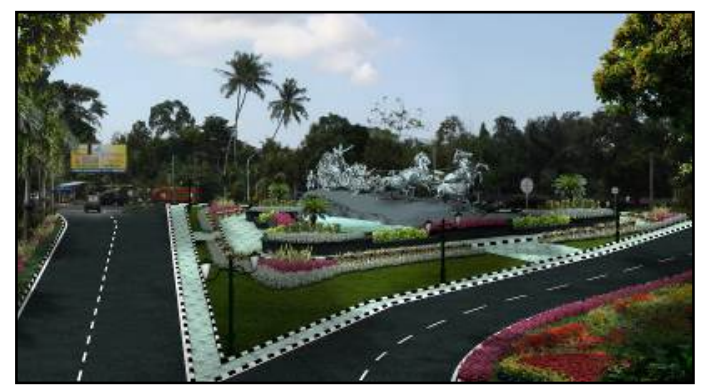

Gambar 4. Konsep Penataan Taman Jalur Hijau Pulau Jalan (DKP, 2013) 


\section{Konsep Penataan Taman Alun-Alun}

Konsep penataan taman alun-alun berlokasi di catus pata puri mengwi sampai dengan jalan menuju taman ayun dengan konsep 6 green. Rencana taman ini memiliki luas kurang lebih $2137,02 \mathrm{~m}^{2}$. Green Transportation berupa jalur pedestrian dari pura taman ayun sampai dengan taman bencingah, Green Waste berupa tempat duduk, dan tempat sampah, Green Energy berupa lampu dengan tenaga surya panel, Green Open Space berupa tanaman jepun (Plumeria rubra) dan Green Building berupa bangunan toilet, vertikal gerden dan papan nama taman

Penggunaan vegetasi pada alun-alun kota diutamakan vegetasi yang mampu menyerap polusi dan debu dengan tajuk pohon yang rapat untuk menciptakan area teduh serta vegetasi dengan perpaduan warna dan tekstur untuk meningkatkan nilai estetika RTH. Penambahan sarana dan prasaran yang disesuaikand engan kebutuhan dan aktivitas masyarakat (area duduk, area berjualan, fasilitas penerangan, fasilitas wifi, fasilitas informasi dan fasilitas kebersihan yang memadai). Adanya landmark patung bima sebagai petanda dan nilai historis kawasan tersebut gambar 5 .

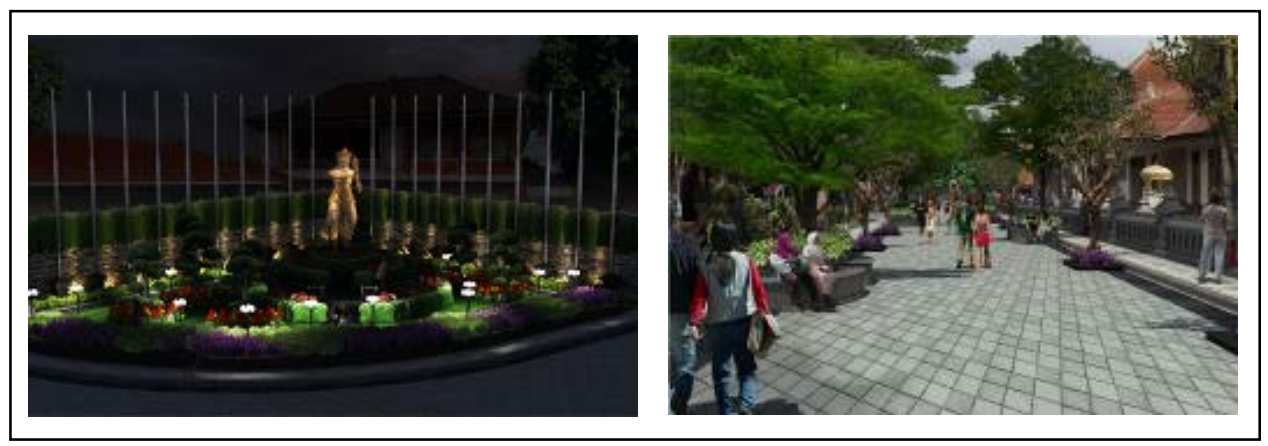

Gambar 5. Konsep Penataan Taman Alun-Alun (DKP, 2014)

\section{Konsep Penataan Taman Lingkungan/ Taman Telajakan}

RTH jenis taman lingkungan atau taman telajakan merupakan RTH yang masih dikelola keberadaannya oleh pemerintah dengan maksud upaya melestarikan budaya lokal yang terkandung didalamnya. Adanya ruang-ruang kosong di depan pekarangan rumah yang membatasi rumah dengan jalan atau yang disebut sebgai taman telajakan yang mempu meningkatkan kualitas pada area pemukiman tersebut. Penataan taman lingkungan atau taman telajakan dengan luasan kurang lebih 69.050,18 $\mathrm{m}^{2}$ sehingga kontribusinya sangat besar bagi peningkatan kuantitas RTH publik. Secara konsep penataan taman lingkungan/ taman telajakan lebih mudah dan penggunaannya hanya menekankan pada green open space. Penggunaan pohon adalah pohon perindang dan jepun (Plumeria rubra). Diutamakan penggunaan vegetasi lokal dengan tanaman perindang dan dikombinasi dengan tanaman semak yang mudah dipelihara oleh masyarakat sekitar gambar 6 .

\section{Simpulan}

Kebutuhan masyarakat kota mengwitani akan ruang terbuka hijau meliputi mampu mengakomodasi fungsi ekologis, fungsi estetika, fungsi ekonomi, fungsi sosial dan budaya. Konsep penataan ruang terbuka hijau publik di Kota Kecamatan Mengwi menerapkan 6 atribut hijau yaitu Green Transportation, Green Waste, Green Water, Green Energy, Green Open Space, dan Green Building. 


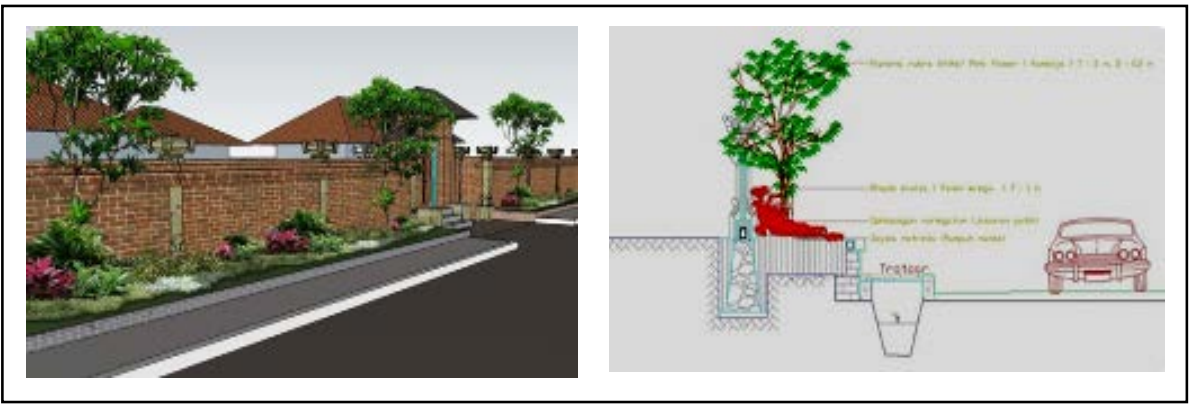

Gambar 6. Konsep Penataan Taman Lingkungan (DKP, 2014)

Secara kuantitas keberadaan taman publik ini akan mampu memberikan kontribusi terhadap bertambahnya keberadaan RTH publik di Kabupaten Badung khususnya di Kota Kecamatan Mengwi dengan luas 86.987,90 $\mathrm{m}^{2}$. Elemen-elemen penunjang konsep penataan ruang terbuka hijau publik berupa aplikasi sarana-sarana 6 atribut hijau yaitu: Green Transportation berupa jalur pejalan kaki, jalur sepeda, jalur kendaraan roda dua dan roda empat, dan parkir kendaraan, Green Waste berupa mesin pencacah sampah dan tepat sampah, Green Water berupa lubang biopori, sumur resapan, dan bak penampungan air, Green Energy berupa surya panel, Green Open Space berupa jepun (Plumeria rubra), keraipayung (Filicium decipiens), Tabebuia perindang (Penta phylla), dan cempaka (Michelia campaca). dan Green Building berupa bangunan toilet, pos penjaga, papan nama, dan bangunan lain yang menggunakan material yang ramah lingkungan.

\section{Daftar Pustaka}

Budihardjo, Eko. 2003, "Kota Berwawasan Lingkungan". Bandung

Darmawan, E. 2009. "Ruang Publik Dalam Arsitektur Kota". Semarang: Badan Penerbit Universitas Diponogoro

Departemen Arsitektur Lansekap IPB. 2005. "Ruang Terbuka Hijau (RTH) Wilayah Perkotaan. Lab. Perencanaan Lansekap Departemen Arsitektur Lanskap Fakultas Pertanian IPB. Bogor.

Dinas Kebersihan dan Pertamanan Kabupaten Badung. Laporan Konsep Kota Hijau Kabupaten Badung. 2013

Dinas Kebersihan dan Pertamanan Kabupaten Badung. Laporan Konsep Kota Hijau Kabupaten Badung. 2014

Hakim, R. dan Hardi, U. 2003. " Komponen Perancangan Arsitektur Lansekap". Cetakan kedua. Jakarta: PT. Bumi Aksara.

Hakim, Rustam. 2004. "Arsitektur Lansekap, Manusia, Alam dan Lingkungan". Jakarta: FALTL Universitas Trisakti.

Instruksi Menteri Dalam Negeri No. 14 Tahun 1988 Tentang : Penataan Ruang Terbuka Hijau Di Wilayah Perkotaan

Undang-undang no 26 tahun 2007 Tentang Penataan Ruang 